\title{
Potential of tungsten tailings as glass raw materials
}

Pura Alfonso ${ }^{a, *}$, Oriol Tomasa ${ }^{b}$, Maite Garcia-Valles ${ }^{b}$, Mariona Tarragób, Salvador Martínez $^{b}$, Hugo Esteves ${ }^{b}$

aDept. de Enginyeria Minera, Industrial i TIC, Universitat Politècnica de Catalunya, Av. de les Bases de Manresa 61-73, 08242 Manresa, Spain

bDept. Mineralogia, Petrologia i Geologia Aplicada, Universitat de Barcelona, C/ Martí i Franquès s/n. 08028 Barcelona, Spain

*Corresponding author. E-mail: maria.pura.alfonso@upc.edu

\section{ABSTRACT}

Glasses from different types of tungsten mine tailings were obtained and studied to determine their ability to be used as raw materials of commercial glass. Tailings of granitic composition from Barruecopardo, of calc-silicate wastes from Morille, and of schists and quartz from Panasqueira, were used as raw materials. The addition of $\mathrm{CaCO}_{3}$ and $\mathrm{NaCO}_{3}$ was necessary for the manufacture of the glass. Samples were characterised by XRF, XRD, HSM and DTA-TG. Furthermore, the expansion coefficient, Vickers microhardness and leaching properties were measured. The results show that all the tungsten mine tailings used were suitable for the manufacture of commercial glass, with the addition of calcium and soda. The calc-silicate tailing needs less additive content to produce a glass. Also, they present lower workability temperatures and higher durability. Glasses obtained from all the tested tailings retain the potentially toxic elements in their structure and prevents the environmental pollution.

Keywords: Recycling, Tailings, Tungsten, Glass.

\section{Introduction}

Tungsten is a critical material for the European Union, which contributes to the opening of new mines in Europe, where tungsten occurs mainly in granitic and calc-silicate deposits. Usually, minerals rich in potentially toxic elements, such as sulphides, 
accompany tungsten ores [1,2]. Thus, the generated tailings constitute an environmental problem that requires short-term solutions to carry out these mining activities in a more environmentally-friendly way.

Vitrification is a technology that stabilizes hazardous wastes, since it renders them in a stable glass or glass-ceramic commercial product $[3,4]$. On the other hand, there are mining wastes with a high potential as raw materials in the production of ceramic, glass and glass-ceramics $[5,6]$. An advantage of these materials is that they have already been processed industrially, and then often have a good homogeneity and a fine particle size. In addition, the costs of extraction are low and this application could be an additional income for mining activities.

In this work, glasses obtained from different types of tungsten mine tailings were studied to determine their ability to be used as raw materials for commercial glass production.

\section{Materials and methods}

\subsection{Materials}

Materials used for this study came from tailings of the most common types of tungsten deposits. Tailings of granitic composition from Barruecopardo (Spain) were previously investigated [7] and here they are compared with wastes from the tailing of veins hosted in schists from Panasqueira (Portugal) and calc-silicate materials from the skarn-type deposit of Morille (Spain).

Dry homogeneous wastes and reactive $\mathrm{CaCO}_{3}$ (PANREAC, cod.121212), and $\mathrm{Na}_{2} \mathrm{CO}_{3}$ (PANREAC, cod.131648) were used to prepare the original glasses.

\subsection{Experimental procedure}

The chemical composition of raw wastes and glasses was determined by X-ray fluorescence (XRF). After evaluating the chemistry of the waste, the original glasses were formulated using a mixture of tailings, $\mathrm{CaCO}_{3}$ and $\mathrm{Na}_{2} \mathrm{CO}_{3}$ (Fig. 1). 


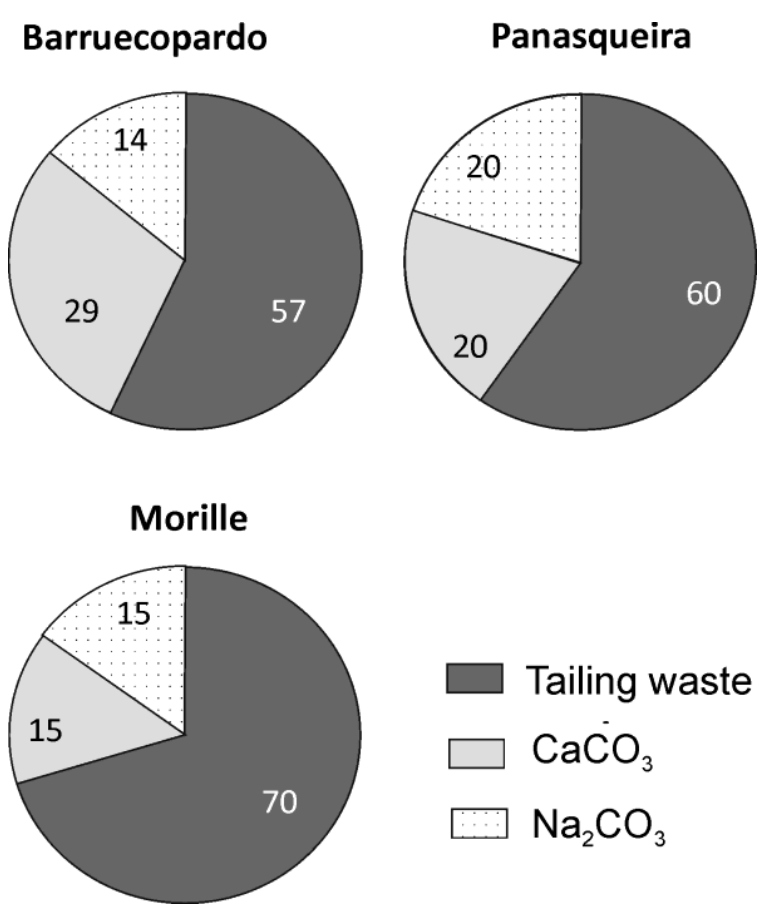

Fig. 1. Composition of the prepared glasses.

The mixed powders were melted in a Pt-Ir crucible at $1450{ }^{\circ} \mathrm{C}$ for $4 \mathrm{~h}$ and quenched in a Cu plate. X-ray powder diffraction (XRD) was used to verify the amorphous structure of the glass and the mineralogy of the neoformed mineral phases induced in thermal treatment. Glass-transition temperature $(\mathrm{Tg})$ analysis and the coefficient of linear expansion were measured by a horizontal dilatometer. The glasses thermal evolution was determined by differential thermal analysis (DTA), using Pt-Rh crucibles, under an air flow of $80 \mathrm{ml} / \mathrm{min}$, and heated at $10^{\circ} \mathrm{C} / \mathrm{min}$. The density of the glass was measured in toluene using the Archimedean method. The viscosity-temperature curves have been plotted from fixed viscosity points determined by hot stage microscopy (HSM) [8] using a Hot-stage processing software [9]. Microhardness was measured on a Galileo Isoscan OD Vickers micro-indenter with a load of $200 \mathrm{~g}$. The chemical stability of the glasses was investigated according to the DIN 38414 S4 method [10], then the analyses were performed by inductively coupled plasma optical emission spectrometry (ICP-OES) and ICP-mass spectrometry (ICP-MS).

\section{Results and discussion}

\subsection{Raw tailing characterization}

The chemical composition of tailing materials and original glass is shown in Table 1a. The highest alkali content is found in the calc-silicate Morille tailing, and the lowest occurs 
in the schist-rich Panasqueira. Barruecopardo has the lowest $\mathrm{Fe}_{2} \mathrm{O}_{3}$ content, 1.12 wt. \%, which is important for obtaining a clear glass.

\subsection{Mechanical properties of glass}

The amorphous structure of the glasses was corroborated by XRD. $\mathrm{T}_{\mathrm{g}}$ is 642 and 664 ${ }^{\circ} \mathrm{C}$ for Barruecopardo and Panasqueira, respectively, whereas it is $569^{\circ} \mathrm{C}$ in Morille.

The coefficient of linear expansion between 20 and $400{ }^{\circ} \mathrm{C}$ is similar in all the cases, being $9.1 \times 10^{-6}{ }^{\circ} \mathrm{C}^{-1}$ for the Pasqueira glass, $11.9 \times 10^{-6}{ }^{\circ} \mathrm{C}^{-1}$ for Barruecopardo and $12.5 \times 10^{-6}$ ${ }^{\circ} \mathrm{C}^{-1}$ for Morille, and are slightly lower than for a soda-lime glass, which is $9.1 \times 10^{-6}$. These results relatively correlate with an Appen's theoretical expansion coefficient $\left(R^{2}=0.9997\right)$ [11].

Density is one of the most important properties for industrial glass production. This is $2.48 \mathrm{~g} / \mathrm{cm}^{3}$ for the Barruecopardo glass, $2.52 \mathrm{~g} / \mathrm{cm}^{3}$ for the Panasqueira glass, and 2.57 $\mathrm{g} / \mathrm{cm}^{3}$ for the Morille glass, which are slightly higher values than a soda lime glass $(2.44$ $\left.\mathrm{g} / \mathrm{cm}^{3}\right)$.

The Vickers microhardness $(\mathrm{Hv})$ are $6.7( \pm 0.5), 6.9( \pm 0.5)$ and $7.4( \pm 0.4) \mathrm{GPa}$, for Morille, Barruecopardo and Panasqueira glasses, respectively, which are higher than the typical 5.36 GPa of conventional silica glasses [12].

\subsection{Thermal evolution}

DTA curves (Fig. 2) show two single exothermic peaks corresponding to the crystallisation temperature $\left(\mathrm{T}_{\mathrm{Cr}}\right)$. The formation of new crystalline phases in the Barruecopardo glass occurs at 771 and $963^{\circ} \mathrm{C}$ and is due to the crystallization of wollastonite and nepheline. In the Morille glass these peaks occur at 776 and $1049^{\circ} \mathrm{C}$, and nepheline, wollastonite and melilite-group minerals formed. In the Panasqueira glass, the two events are close at 873 and $905^{\circ} \mathrm{C}$, mainly corresponding to nepheline and a minor content of plagioclase. The endothermic peak occurs between 1132 and $1246^{\circ} \mathrm{C}$ and is attributed to melting of neoformed minerals. 


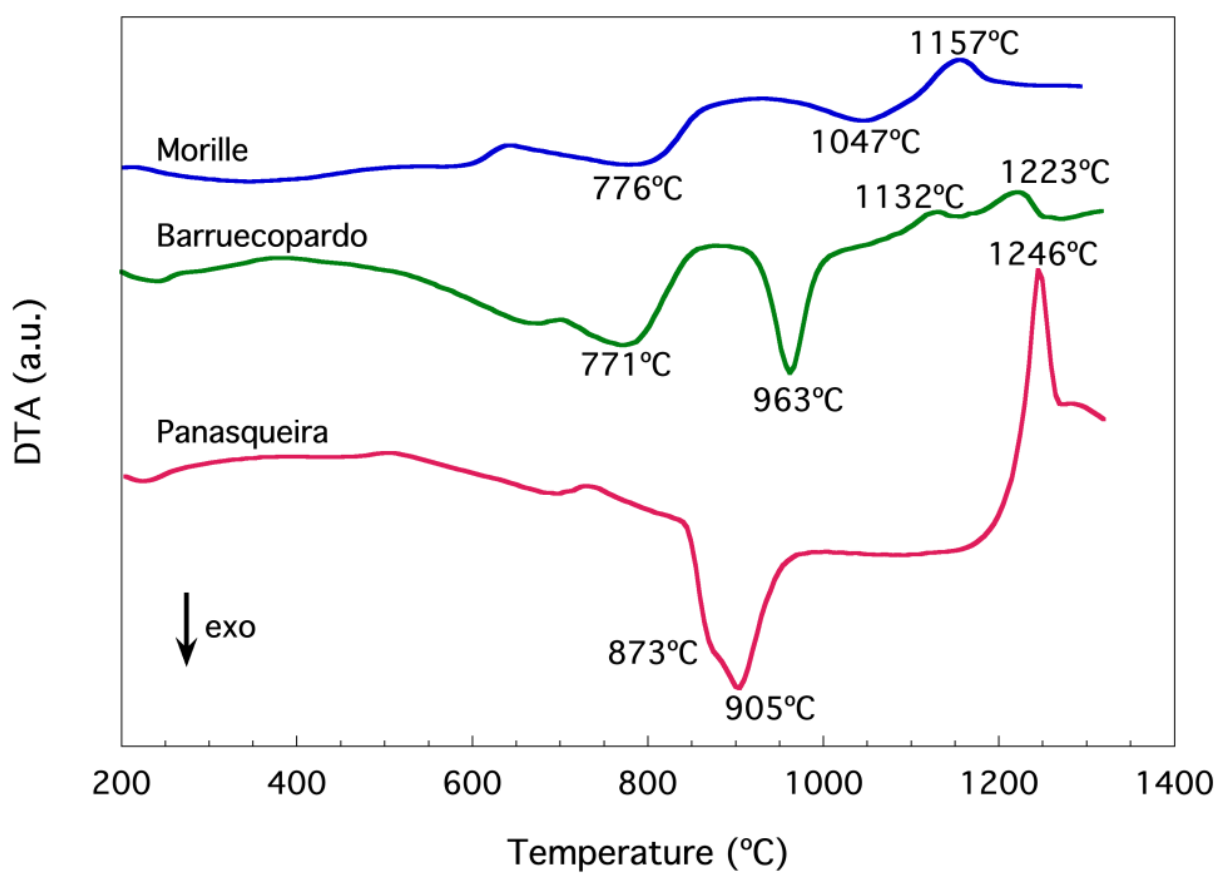

Fig. 2. DTA curves from original glasses.

The rheological behaviour of the studied glasses, as well as the comparison with a soda-calcium common glass, is presented in Fig. 2. The decrease in viscosity with increasing temperature is non-Arrhenius and deviates from the normal behaviour of a viscous flow as the compositions enter into the crystallization range (especially remarkable below $\left.10^{8} \mathrm{~Pa} \cdot \mathrm{s}\right)$. Hence, the reported values correspond to the apparent viscosities of crystal-glass-melt mixtures. The melts of modified mine waste compositions are sensibly more viscous than the soda-lime melt.

Working temperatures to produce the Morille glass are lower than in the other two samples. Thus, the energy consumption necessary for the temperature treatment will be lower to produce the Morille glass that the other two glasses. 


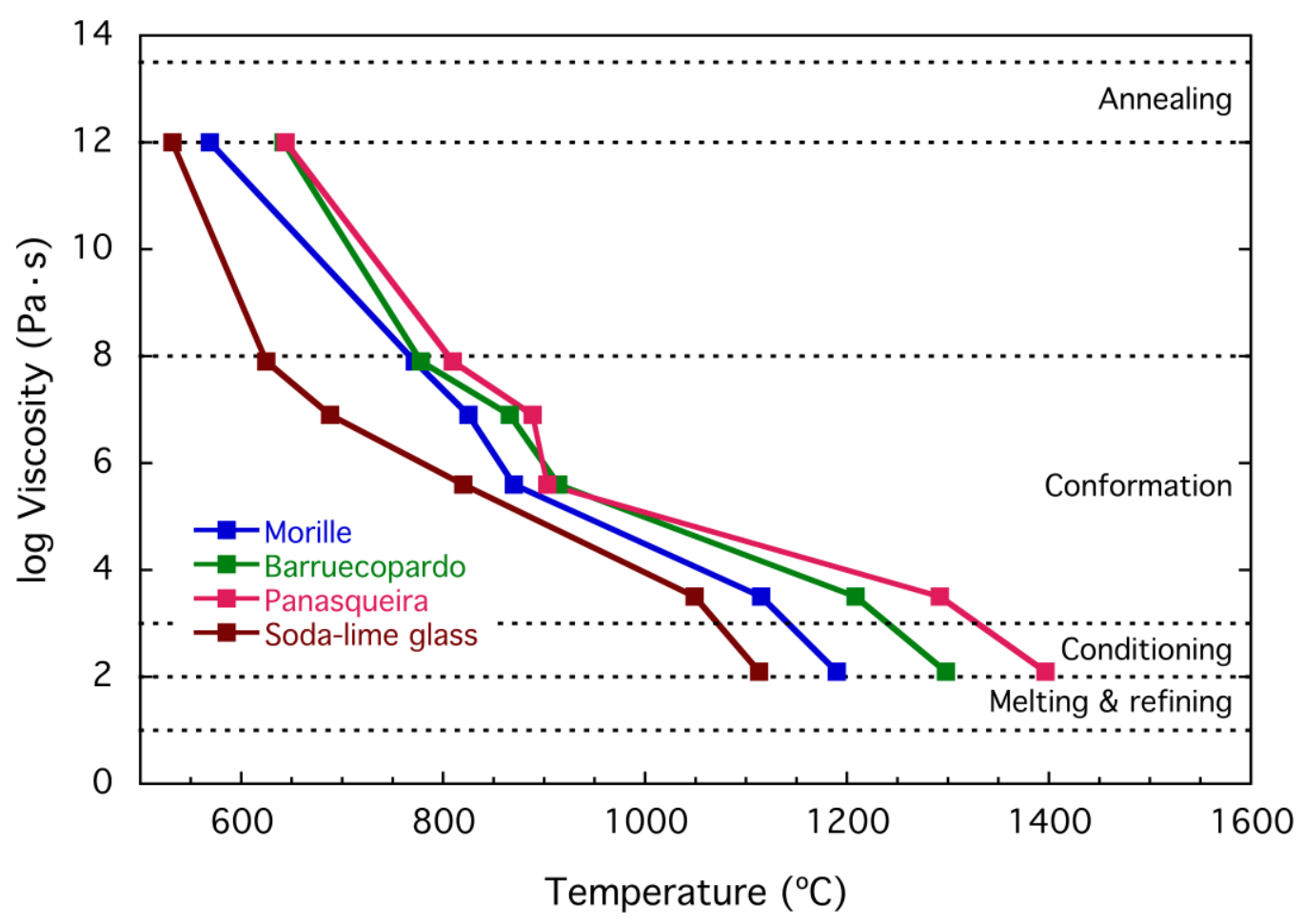

Fig. 3. Viscosity-temperature curves and workability intervals of the studied glasses, as well as comparison with a soda-lime glass.

Depending on the rheological behaviour of glass in the working viscosity interval, $10^{6}$ $10^{3} \mathrm{~Pa} \cdot \mathrm{s}$, glasses can be classified into short and long types [13], depending on whether this interval of temperature is lower or higher than $400^{\circ} \mathrm{C}$, respectively. Short glasses are more suitable for processing in an automatic system due their narrow viscosity range. In this work, the temperature intervals are $333^{\circ} \mathrm{C}, 285{ }^{\circ} \mathrm{C}$ and $236{ }^{\circ} \mathrm{C}$ for the Panasqueira, Barruecopardo, and Morille glasses, respectively all of which are appropriate for automatic processing.

\subsection{Leachability}

Tailings from Barruecopardo [1] and from Panasqueira [2,14] produce runoff waters with high metal concentrations. In contrast, the metal contents of leachates from the obtained glasses (Table 1b) are lower than the one indicated in the DIN 38414 S4 to be considered as inert [9]; hence, the metals were fixed in the structure of these glasses. 
Table 1a

Chemical composition of the tailing raw materials and the formulated glasses.

\begin{tabular}{lrrrrrr}
\hline Oxide (wt.\%) & Bp-t & Mo-t & Pan-t & Bp-g & Mo-g & Pan-g \\
\hline $\mathrm{SiO}_{2}$ & 73.98 & 62.50 & 66.90 & 55.96 & 53.21 & 51.13 \\
$\mathrm{Al}_{2} \mathrm{O}_{3}$ & 13.41 & 13.35 & 15.05 & 10.15 & 12.99 & 11.50 \\
$\mathrm{TiO}_{2}$ & 0.14 & 0.55 & 0.75 & 0.11 & 0.40 & 0.57 \\
$\mathrm{Fe}_{2} \mathrm{O}_{3}$ & 1.12 & 3.76 & 6.29 & 0.84 & 3.55 & 4.81 \\
$\mathrm{MnO}$ & 0.01 & 0.18 & 0.05 & 0.01 & 0.11 & 0.04 \\
$\mathrm{Na}_{2} \mathrm{O}$ & 2.77 & 1.99 & 0.92 & 8.09 & 11.46 & 15.12 \\
$\mathrm{MgO}$ & 0.26 & 1.63 & 1.94 & 0.19 & 1.88 & 1.48 \\
$\mathrm{CaO}$ & 0.51 & 9.6 & 0.33 & 20.38 & 14.58 & 12.69 \\
$\mathrm{~K}_{2} \mathrm{O}$ & 5.29 & 1.03 & 3.22 & 4.00 & 1.19 & 2.46 \\
$\mathrm{P}_{2} \mathrm{O}$ & 0.36 & 1.18 & 0.19 & 0.27 & 0.64 & 0.15 \\
$\mathrm{LOI}$ & 2.19 & 2.05 & 2.49 & - & - & - \\
\hline
\end{tabular}

Bp, Barruecopardo; Mo, Morille; Pan, Panasqueira; t, tailing; g, glass.

\section{Table 1b}

Chemical composition (ppb) of leachates from the glasses.

\begin{tabular}{lcrrr}
\hline Metal (ppb) & TL & Mo-Ix & Pan-lx & Bp-Ix \\
\hline $\mathrm{Zn}$ & 4000 & 12.7 & 19.8 & 8.9 \\
$\mathrm{Cd}$ & 40 & 0.1 & 0.1 & 0.1 \\
$\mathrm{~Pb}$ & 500 & 47.2 & 203.1 & 3.2 \\
$\mathrm{As}$ & 500 & 2.7 & 31.4 & 10.8 \\
$\mathrm{Cu}$ & 2000 & 18.6 & 17.9 & 17.2 \\
$\mathrm{Cr}$ & 500 & 1.78 & 2.9 & 0.9 \\
$\mathrm{Ni}$ & 400 & 4.7 & 3.4 & 11.0 \\
$\mathrm{~W}$ & - & 9.7 & 10.2 & 13.8 \\
$\mathrm{Sn}$ & - & 0.7 & 0.3 & 0.1 \\
\hline \multicolumn{4}{c}{ TL, threshold limits according to the DIN 38414-S4 method. }
\end{tabular}

\section{Conclusions}

All the tungsten mine tailings used were suitable for making glass, with the addition of calcium and sodium. However, those with calc-silicate composition have several advantages:

(1) They need a lower content of additives.

(2) The workability temperatures are lower than in the other glasses, which means that lower energy consumption is necessary for the temperature treatment during the he glass manufacture.

(3) These glasses show a lower $\mathrm{Al}_{2} \mathrm{O}_{3} / \mathrm{Na}_{2} \mathrm{O}$ ratio, which is indicative of greater durability.

Glasses obtained from all the tested tailings retain the potentially toxic elements and prevent the environmental pollution. Then, the production of glass using these wastes can be useful to avoid pollution of tailings after the ore processing. 


\section{Acknowledgements}

The authors thank the staff of the CCiT-UB for their technical support. M. Tarragó received a PhD grant from the Ministerio de Educación, Cultura y Deporte (FPU13/04507). Plymouth Minerals and especially D. Valls helped in the sampling.

\section{References}

[1] V. Otones, E. Álvarez-Ayuso, A. García-Sánchez, I. Santa Regina, A. Murciego, Arsenic distribution in soils and plants of an arsenic impacted former mining area, Environ. Pollut. 159 (2011) 2637-2647.

[2] C. Candeias, R. Melo, P.F. Ávila, E.F. da Silva, A.R. Salgueiro, J.P. Teixeira, Heavy metal pollution in mine-soil-plant system in S. Francisco de Assis-Panasqueira mine (Portugal). Appl. Geochem. 44 (2014) 12-26.

[3] P.A. Bingham, R.J. Hand, Vitrified metal finishing wastes: I. Composition, density and chemical durability, J. Hazard. Mater. 119 (2005) 125-133.

[4] P.A. Bingham, R.J. Hand, S.D. Forder, A. Lavaysierre, Thermal and structural characterisation, J. Hazard. Mater. 122 (2005) 129-138.

[5] L. Baowei, D. Leibo, Z. Xuefeng, J. Xiaolin, Structure and performance of glass-ceramics obtained by Bayan Obo tailing and fly ash, J. Non-Crystalline Solids 380 (2013) 103-108.

[6] F. He, J. Liu, J. Cheng, Study on sintered glass ceramics from Nb-Ta tailings, Glass Phys. Chem. 38 (2012) 109-115.

[7] P. Alfonso, D. Castro, M. Garcia-Valles, M. Tarragó, O. Tomasa, S. Martínez, Recycling of tailings from the Barruecopardo tungsten deposit for the production of glass, J. Therm. Anal. Calorim. 125 (2016) 681-687.

[8] M.J. Pascual, L. Pascual, A. Duran, Determination of the viscosity-temperature curve for glasses on the basis of fixed viscosity-temperature determined by hot stage microscopy, Phys. Chem. Glasses 42 (2001) 61-66.

[9] M. Garcia-Valles, H.S. Hafez, I. Cruz-Matías, E. Vergés, M.H. Aly, J. Nogués, D. Ayala, S. Martínez, Calculation of viscosity-temperature curves for glass obtained from four wastewater treatment plants in Egypt, J. Therm. Anal. Calorim. 111 (2003) 107-114

[10] DIN 38414 S4, Deutsche Einheisverfahren zur Wasser, Abwasserund Schlammuntersuchung, Bestimmung der Eluierbarkeit von Wasser (S4), 1984.

[11] A.A. Appen, Versuch zur Klassifizierrung von Komponenten nach ihrem Einfluß auf die Oberflächenspannung von Silikatschmenlzen. Silikattechnik, 5 (1954) 113-124.

[12] G.F.T. Lay, M.C. Rockwell, J.C. Wiltshire, C. Ketata, Characteristics of silicate glasses derived from vitrification of manganese crust tailings, Ceram. Int. 35 (2009) 1961-1967.

[13] M.B. Volf,Technical Glasses. Pitman and Sons, London, 1961.

[14] C. Candeias, R. Melo, P.F. Ávila, E.F. da Silva, A. Salgueiro, J.P. Teixeira, Heavy metal pollution in mine-soil-plant system in S. Francisco de Assis-Panasqueira mine (Portugal). Appl. Geochem., 44 (2014) 12-26. 